\title{
The Implementation of the Quality Control System Policy of Land Program in East Nusa Tenggara Province's Office Performance of National Land Agency
}

\author{
(1) Yanes Mikhael Pello \\ (2) Aloysius Liliweri \\ (3) Nursalam \\ Master's Degree Program in Administrative Sciences, Universitas Nusa Cendana Kupang, East Nusa Tenggara, \\ Indonesia
}

\begin{abstract}
This study examined the Implementation of the Quality Control System Policy of Land Program in East Nusa Tenggara Province's Office Performance of National Land Agency. This study aimed to find out, describe, and analyze the Implementation of the Quality Control System Policy of Land Program in East Nusa Tenggara Province's Office Performance of National Land Agency. This research was a case study with an inductive approach. The focus of this research was implementing the Quality Control System Policy of Land Program in East Nusa Tenggara Province's Office Performance of National Land Agency. The research sub-focus was on the factors of communication, resources, disposition, and bureaucratic structure. The informants were determined by purposive technique. The type of data was primary and secondary data. Data collection techniques used was interviews, documentation, and observation. Analysis of the data used in this study was proposed by Miles and Huberman (2007). Validity checking applied for the findings/conclusions was the triangulation technique.The results showed that the communication at the East Nusa Tenggara Province's Office Performance of National Land Agency related to the Land Programs' Quality Control System went well. However, the self-awareness to fill the results of completion at each stage of activities into the Land Program Quality Control System or Sistem Kendali Mutu Program Pertanahan (SKMPP) reporting application should be strengthened to avoid the procrastination in data charging due to other works. Besides, the resources in the form of apparatus and facilities to implement the SKMPP were adequate, but the problem was that the apparatus prioritized the completion and reporting of work/activities in their respective fields and forgetting to enter data on the SKMPP. Furthermore, the disposition carried out by officials in handling the arrangement of street vendors was excellent, but incentives must be taken into account for the officials who carried out the policy. Finally, the bureaucratic structure related to the operational standards and the spread of responsibilities in implementing the SKMPP had been perfect, but the implementing apparatus had not seen any significant changes.
\end{abstract}

Keywords: Implementation, Policy, System, Program, Performance, Land

DOI: $10.7176 / \mathrm{PPAR} / 10-9-05$

Publication date:September $30^{\text {th }} 2020$

\section{BACKGROUND}

Up to 2015, East Nusa Tenggara Province's Office of National Land Agency still reported the performance reports of each work unit manually through the Government Institution Performance Accountability Report. Later on, in 2016, it used the Government Agency Performance Accountability reporting done manually without being supported by the SKMPP data, an electronic performance reporting by the Ministry of Agriculture and Spatial Planning/National Land Agency.

The description of achievements towards the performance of work units within East Nusa Tenggara Province's Office of National Land Agency can be seen from the Institutional Performance Accountability Reports or Laporan Akuntabilitas Kinerja Instansi Pemerintah (LAKIP) as follows:

Table 1.1. Achievement Realization of Institutional Performance Accountability Reports

Of 2010 until 2017

\begin{tabular}{|r|r|r|r|}
\hline \multirow{2}{*}{ Year } & \multicolumn{2}{|c|}{ Achievement Realization } & Description \\
\hline 2010 & $101.37 \%$ & $77.11 \%$ & \\
\hline 2011 & $105.97 \%$ & $80.04 \%$ & \\
\hline 2012 & $101.32 \%$ & $85.07 \%$ & \multirow{3}{*}{ Physical Realization of activities beyond } \\
the target \\
\hline 2013 & $101.64 \%$ & $86.32 \%$ & \\
\hline 2014 & $109.06 \%$ & $89.66 \%$ & \\
\hline 2015 & $102.04 \%$ & $90.25 \%$ & \\
\hline 2016 & $92.28 \%$ & $92.06 \%$ & \\
\hline
\end{tabular}

Source: East Nusa Tenggara National Land Agency, 2019

The table above explains that the realization of the performance of East Nusa Tenggara National Land Agency 
in 2010 until 2017 reached the target, where the realization of existing physical activity exceeds the target. East Nusa Tenggara Province's Office of National Land Agency requires changes in organizational governance to improve land services, especially the quality control of land programs implemented to boost the apparatus' performance, so there is a need for a quality control system from the organizational performance.

From 2007 to 2009, the National Land Management Information and Management System was developed, but it could not answer all the information and control of the programs by the National Land Agency. Therefore, the quality control system was developed in 2019 as a development of the Land Program Quality Control System or Sistem Kendali Mutu Program Pertanahan (SIMTANAS).

SKMPP is part of the internal control system within the Ministry of Agrarian Affairs, and Spatial Planning/National Land Agency of the Republic of Indonesia in ensuring programs in the land sector to run as it plans. SKMPP is set out in the form of an application system that will become an integral part of the planning and management system to regulate and direct every activity. SKMPP is a Supporting System for the implementation and achievement of bureaucratic reforms that have been running at the Ministry of Agrarian Affairs and Spatial Planning/National Land Agency, especially East Nusa Tenggara Province's Office of National Land Agency. SKMPP is not only a reporting system that shows performance but is expected to improve public services in the land sector.

East Nusa Tenggara Province's Office of National Land Agency with twenty-two Regency/City Land Offices needs a system that can collect data regionally to be accessed nationally and provide accountable and representative data.

As a reporting system that shows performance, SKMPP has not been carried out to the full and orderly in East Nusa Tenggara Province's Office of National Land Agency. Based on the information from the Head of Administration Section, the problem in implementing the SKMPP policy is the communication, resources, and attitudes of the implementers. According to the background, the writer will conduct research on "The Implementation of the Quality Control System Policy of Land Program in East Nusa Tenggara Province's Office Performance of National Land Agency."

This study aims to determine, describe, and analyze the Implementation of the Quality Control System Policy of Land Program in East Nusa Tenggara Province's Office Performance of National Land Agency. Besides, this research also has theoretical benefits and practical benefits. The intended theoretical benefit is to contribute thoughts to the field of public administration and be used as data or references, further examining the same problem. It can also be input into the East Nusa Tenggara Province's Office of National Land Agency to improve the community's services through the SKKMP. Also, the practical problem referred to is that it can provide benefits to the community as information material to better know about the role of the National Land Agency in improving Public Services through the SKMPP implemented by the East Nusa Tenggara Province's Office of National Land Agency. In addition, the SKKMP can help East Nusa Tenggara Province's Office of National Land Agency to improve the efficiency and effectiveness of land services.

\section{LITERATURE REVIEW}

\section{Public Policy}

In its implementation, this public policy must be derived in a series of implementation instructions and technical guidelines that apply internally in the bureaucracy. Meanwhile, from the community side, what essential is the standard of public service, describing what services it is entitled to, who is accustomed to getting them, what are the requirements, as well as what form of service. This will bind the government (state) as the service provider and the community as the service recipient.

According to James E. Annderson (in Islamy 2001: 17), a policy is "a series of actions that have a specific purpose followed and implemented by a principal or group of actors to solve a particular problem." The term public policy is more often used concerning government actions or activities. It is as stated by Carl J. Friedrick (in Solichin, 2004: 3) that policy is "An action that leads to the goals proposed by a person, group, or government in a particular environment regarding certain obstacles while looking for opportunities to achieve goals or desired goals." The definition of the policies mentioned above is an action proposed by the government. It is different from the opinion of George C. Edwads III and Ira Sharkansky (in Islamy, 2001) that "State Policy is an action taken or not by the government" so that a policy is not only a proposed but also not implemented action.

Some opinions above show that public policy taken by the government is to achieve goals and objectives for the benefit of the whole community to accommodate the values in society, whether done or not. This understanding is in line with the opinion of Islamy (2001: 20) that "State policy is a set of actions determined and implemented or not carried out by governments that have goals or are oriented towards the interests of the whole community."

The State Policy can be in the form of laws and regulations used for the purposes, objectives of the programs, and actions taken by the government. From the understanding of public policy above, it is concluded that the policy is a set of government to respond problems faced by the community and have specific goals, oriented to the interests of the public (community), and aims to overcome problems, meet the desires and demands of all members 
of the community. The policy also includes all actions taken or not by the government in which there is an element of coercion to the implementation or policy users to be obeyed. This is in line with Easton's opinion (in Islamy, 2001: 19) that the policy contains legitimate coercive values the government can do as a policymaker.

\section{Policy Implementation}

Policy implementation seen in a broad sense is a legal administration tool in which various actors, organizations, procedures, and techniques work together to carry out policies to achieve the desired impact or goals. (Lester and Steewart, 2000: 104). On the other hand, implementation is a complex phenomenon that may be understood as a process, an output, or an outcome. Van Meter and Van Horn (in Winarno, 2002: 102) limit the implementation of policies as actions taken by the government and private individuals directed to achieve the goals set in policy decisions. These actions included efforts to change decisions into operational actions within a certain period and to continue efforts to achieve major and minor changes determined by policy decisions. What needs to be emphasized here is that the policy implementation phase will not begin before objectives and recommendations are established or identified by policy decisions. Thus, the implementation phase occurs only after laws are enacted, and funds are provided to finance the policy's implementation.

The implementation model's application is the stage of implementation by policymakers and the people they influence according to the objectives; if the implementation is not appropriate, it will not reduce the problem and even fail. Furthermore, Van Meter and Van Horn (in Solichin, 2004: 81), in their policy implementation model, also assume that communication factors will be influential, namely, communication between related organizations and their implementation activities, including relationships in the political system environment with target groups. Van Meter expects that all executors must understand what is idealized by policies whose implementation is their responsibility, superior organizations should be able to condition subordinate or executors, because in the implementation of a program needs support and coordination with other agencies; thus, it requires coordination and cooperation for success a program.

According to Van Meter and Van Horn (in Winarno, 2002: 122), successful implementation is a function of the ability of the implementing organization to do what is expected to do. Van Meter and Van Horn also suggest that capacity is an influential factor for policy implementation. On the other hands, Van Meter and Van Horn (in Winarno, 2002: 12) suggest that the ability to implement policies may be hampered by factors such as poorly trained staff and too much work, inadequate information and financial resources, or impossible time constraints. In more detail, Van Meter and Van Horn (in Winarno, 2002) formulate an abstraction (framework) that shows the relationship between various factors that influence the results of policy.

Policy implementation intentionally carried out to achieve high performance occurs in the interrelationship of various factors and is developed in a policy implementation model that consists of six variables believed to form the relationship between policy and policy performance: (1) policy standards and objectives, (2) policy resources (funds and other incentives), (3) communication between organizations and measurement of activities, (4) characteristics of executor agencies (such as staff size, level of hierarchical oversight, organizational vitality), (5) socio-economic and political conditions, and (6) the attitude of the executors;

Figure 2.1

Van Meter and Van Horn's Implementation Model

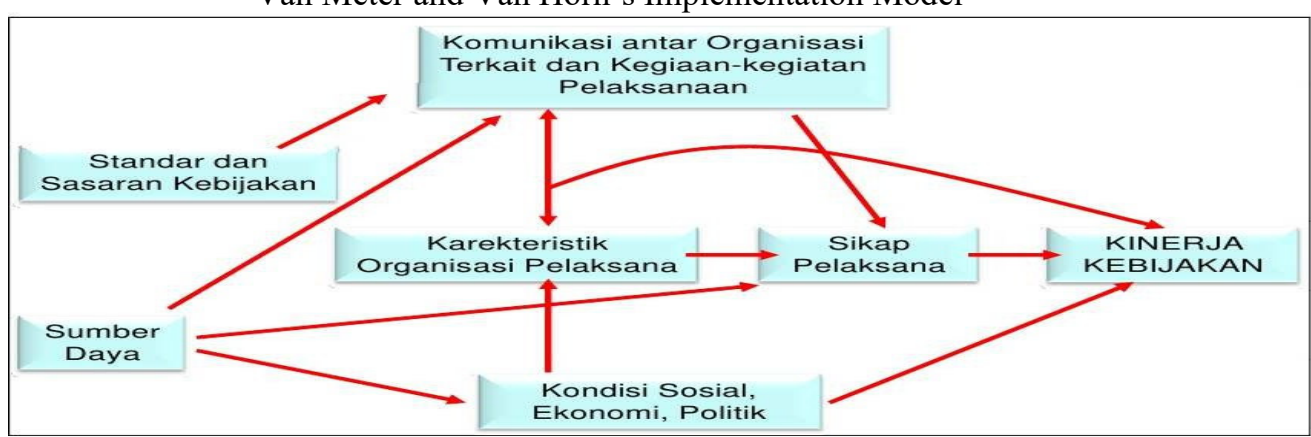

Source: Wibawa (1994:19)

\section{Policy Implementation Model}

The models of policy implementation from various experts are basically to provide the factors that influence the success of policy implementation. George C. Edward III stated several things that could affect the success of Policy Implementation: (1) Communication; (2) Resources; (3) Dispositions; (4) Bureaucratic Structure (Edward III, 1980: 10). Each factor is interconnected with one another, then jointly influences the implementation, and indirectly influences each of the other factors. The following is the figure model of policy implementation by Edward III: 
Figure 2.2

Implementation Approach Model According to Edward III

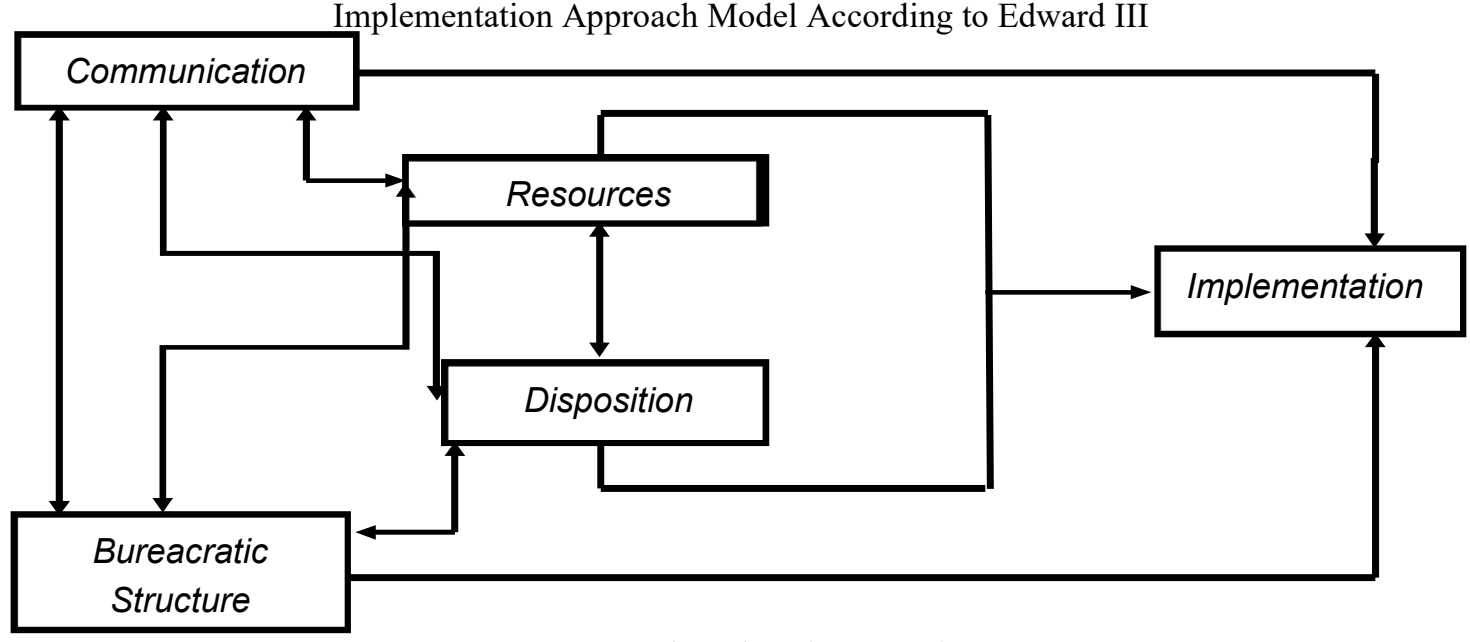

Source Edward III (1980:148)

Based on the figure above, this process is an abstraction or performance of a policy, basically carried out to achieve high performance of public policy implementation, taking place in the relationship of various variables.

This model likens the implementation of the policy runs linearly from communication, available resources, disposition, and application of policy implementation. According to Edward III, communications "have an important role as a reference for implementing the policy, knowing what will be done. It means that communication is also expressed by orders from superiors on the implementation of policies, so communication must be stated clearly, quickly, and consistently." (Edward III, 1980:10)

Based on this definition, communication is crucial in achieving the objectives of implementing public policy. Implementation will occur if the decision-makers already know what will be done.

\section{Concept of Performance}

According to Setiawan (1988: 9), "Performance relates to the assessment of the management quality and the quality of the tasks implementation or company's operations. Another aspect is the relationship between the organization and its political environment." When examined from the main objectives and mission, the objective of public organizations is to meet the public's needs and interests (Dwiyanto, 1995), so the performance of the public organization can only be said to be successful if it is able to realize its goals and mission.

Levine et al. (in Dwiyanto, 1995) put forward three concepts to be a reference for measuring the performance of public organizations; (1) Responsiveness refers to the harmony between programs and service activities provided by public organizations with the needs and desires of the community. (2) Responsibility explains the extent to which the implementation of public organization's activities is carried out following the correct principles of administration under the organizational policies, both implicitly and explicitly. (3) Accountability refers to how much the policy and activities of public organizations are subject to political officials elected by the people. In this context, the performance of public organizations is considered good if all or at least most of their activities are based on efforts to meet the hopes and desires of the people's representatives.

\section{METHODOLOGY}

The approach used in this study was an inductive (qualitative) research because it starts from observation, patterns, hypotheses, theory (Liliweri; 2018: 27). This type of research is a case study of the implementation of the SKKMP policy at East Nusa Tenggara Province's Office of National Land Agency. This research was carried out at at East Nusa Tenggara Province's Office of National Land Agency. The focus of this research was implementing the SKKMP in East Nusa Tenggara Province's Office performance of National Land Agency. The sub-focus of the research was on the factors of communication, resources, disposition, and bureaucratic structure that, according to the author, was under the conditions or phenomena that appear at East Nusa Tenggara Province's Office of National Land Agency. The informants were determined by using a purposive technique with certain considerations. They are Echelon officials II, Echeleon officials III, Echelon officials IV, General Functional Officers, and Application Operators. In this research, the type of data collected was primary and secondary data. Data collection techniques used was interviews, documentation, and observation. Analysis of the data used in this study was proposed by Miles and Huberman (2007). Validity checking applied for the findings/conclusions was the triangulation technique. 


\section{RESULTS}

To discuss the success of the SKKMP, the author uses the opinion of Edward III (1980) namely, communication, resources, disposition, organizational structure.

\section{Communication}

Communication is the process of delivering information from the apparatus that has the function of structuring as the executor of SKKMP policy at East Nusa Tenggara Province's Office of National Land Agency. Policy communication in handling the SKKMP was carried out by conducting socialization in dialogue or sermon.

From the research results, it was known that most of the staff knew about the application of the SKKMP, but they do not think it was crucial. The results also found that the communication built by East Nusa Tenggara Province's Office of National Land Agency to the SKKMP went well. However, the self-awareness to fill the results of completion at each stage of activities into SKMPP reporting application should be strengthened to avoid the procrastination in data charging due to other works.

Self-awareness is an individual's ability to know what she/he feels and use it to direct self-decision making, having realistic benchmarks of self-ability, and strong self-confidence. Self-awareness is within us, without anyone else knowing about something that we are experiencing. Self-awareness has a clear perception of personality, including thoughts, beliefs, emotions, strengths, weaknesses, and motivations. Self-awareness helps to understand others, how they value others, attitudes, and responses to others. Self-awareness is the key to a change in life. Everyone who wants to be better must be based and desire to change into a better person. Changes not based on awareness to grow and change will make it easier for them to stop struggling halfway.

However, in fact, not everyone has good self-awareness, which sometimes can cause conflict. In the end, it can lead to division and also conflict. This is the reason why self-awareness is critical in communication.

\section{Resources}

Human resources needed were those having extensive expertise and knowledge on technical guidelines for the SKKMP. Information about the SKKMP was direct information from the Nusa Tenggara Province's Office of National Land Agency. Infrastructure is a supporting resource for the implementation of the SKKMP in Nusa Tenggara Province's Office of National Land Agency.

Related to human resources in handling the SKKMP of the East Nusa Tenggara Province's Office of National Land Agency, all of them have the quality and ability to access and fill the SKKMP by the Decree of the Nusa Tenggara Province's Office of National Land Agency. However, the problem is that the executors think it is not too important, so they are not serious about doing it. Also, the existing human resources were good enough to implement the SKKMP. Based on the results of the study, the resources related to human resources in implementing the SKKMP were excellent and therefore needed to be increased again.

If the organization already has a significant capital, sophisticated technology, and abundant natural resources, but having no human resources to manage and utilize, it will not be possible to achieve organizational goals. That is why the importance of human resources in the organization is truly needed as the primary and controlling element of organizational success. Information is a vital resource in the policy process because it is used as the SKKMP policy's contents. Good information can lead to the sustainability of useful and precise policy.

Referring to information resources, the study results revealed that information about the SKKMP has been conveyed to all officials in East Nusa Tenggara Province's Office of National Land Agency. Even before going to the field, it is always reminded to fill in the application of SKKMP once the fieldwork finished. In addition, all officials also know how to manage the SKKMP. It can be concluded that related to information resources, the apparatus of East Nusa Tenggara Province's Office of National Land Agency has the skills regarding the SKKMP.

A leader needs to understand computers because he must manage resources to achieve problem-solving and decision-making. The resources that must be managed by a leader include humans, materials, machines, money, and information. Of the five resources, the first four are commonly referred to as physical resources, while the fifth one is conceptual resources. Managers use conceptual resources to manage physical resources. A manager must collect data to be processed into information. Later on, a manager must ensure that anyone suitable in the organization receives information.

Facilities (infrastructure) are needed to support the performance of the apparatus in managing SKMPP. Through adequate facility support, it results in effective and efficient implementation as well as satisfaction for the organization. The facilities needed to implement the SKMPP policy must be fulfilled because it is impossible to run effectively without them.

The research results showed that to support the excellent implementation of SKKMP, East Nusa Tenggara Province's Office of National Land Agency also has the task of preparing facilities for the apparatus, such as laptops/computers, internet networks, etc. It was said that the facilities for the apparatuses have been prepared by the East Nusa Tenggara National Land Agency (government), but the apparatus do not fully utilize these facilities for various reasons. For that matter, the government must always conduct socialization to the apparatus to take 
advantage of these facilities to support the activities of SKMPP running well.

Although it is always a couple, facilities and infrastructure have a different meaning and function. Means are all things that can be used as tools and materials to achieve the production process's goals and objectives. Meanwhile, infrastructure is everything that becomes the primary support for the implementation of production.

\section{Disposition}

The disposition or the executors' attitude is an essential factor in implementing a public-policy approach. If it wants to achieve effective implementation, the executors must know what will be done and implement it, so there will be no biased in practice. Therefore, the important thing is the extent to which the policy implementation team has an active role in implementing the SKKMP. The influence of disposition raises real obstacles in implementing the SKKMP policy. The level of commitment and honesty of the apparatus in policy implementation is the most important thing in disposition because the policy implementation can affect the desire and willingness to carry out a policy. The desires and wishes of an apparatus can be seen from the knowledge of a policy implemented, understanding and deepening of a policy and acceptance of the apparatus in the policy whether to accept, reject or neutral.

The research results found that all the officials at East Nusa Tenggara Province's Office of National Land Agency knew the disposition of policies related to the SKPPM. However, the executors consider not necessary because of other workloads to finish, road assignments, etc., which finally resulted in work delays in entering data into the application of SKMPP. In addition, the results of the study also found that all the officials ar East Nusa Tenggara Province's Office of National Land Agency knew the disposition of policies related to the SKPPM. However, the executors consider not necessary because they were focus in their work. Based on these findings, it can be said that in implementing policies related to the SKMPP, the level of propriety of the government apparatus, in this case, East Nusa Tenggara Province's Office of National Land Agency, has been excellent but the problem comes from the implementers themselves who do likes to postpone to enter data on the SKMPP.

Incentives are a motivational tool that encourages apparatus to carry out obligations with optimal abilities. The research results indicate that the incentives are given to the executorsa of SKMPP to provide motivation and encouragement so that they could implement the SKMPP well, but the provision of these incentives was recognized as being too late. Even though it was late, the implementation of the SKMPP continued well, despite the delay in entering data. Based on these findings, it can be explained that the provision of incentives for the implementation of the SKMPP exists even though it is often late and the process of implementing the SKMPP is still ongoing.

Disposition should no longer be a trigger for internal problems of East Nusa Tenggara Province's Office of National Land Agency. For example, there are delays in disposition follow-up, ignorance of disposition status, or even not knowing the position of disposition. Things like that could be one of the problems of correspondence at East Nusa Tenggara Province's Office of National Land Agency.

Tracking of dispositions digitally is essential because of its ease in monitoring the position of letter dispositions. The agency's secretary or admin no longer needs to pace the leadership room to submit a letter disposition. Not to mention if there are problems with illegible letters, slip letters, missing letters, or other problems. Digitization in disposition tracking addresses the issue of correspondence at East Nusa Tenggara Province's Office of National Land Agency. All data is stored in a database that can be accessed anytime, anywhere. Disposition of letters can be done even if the leader is not in the office. This can minimize the delay in follow-up dispositions.

Apart from the easier system, the use of information and communication technology in tracking disposition also provides convenience in accessing services for users. Admin no longer recaps outgoing mail, incoming mail, and disposition letters manually. Disposition tracking is digitally and automatically stored in a computer database. For example, you can monitor the number of dispositions that have been sent, read, and approved. If there is an error, the disposition of the letter can be repaired as early as possible. More than that, digital disposition tracking can be accessed not only via PC or computer but can also via mobile phones, iPads, tablets, and other communication devices. Therefore, monitoring can be done anytime and anywhere.

From the discussion above, it can be concluded that digitizing disposition tracking is very important to avoid unwanted things and speed up the follow-up process. There is now an available database or electronic disposition system that we can use.

\section{Bureaucratic Structure}

The organizational structure is in charge of implementing the policy and has a significant influence on the policy's implementation. One important structural aspect of each organization is the existence of standard operating procedures, meaning a standardization process carried out by East Nusa Tenggara Province's Office of National Land Agency in implementing the SKMPP. The role of the bureaucratic structure is significant in implementing the SKMPP because the organizational structure covers the SOP and also the distribution of responsibilities for managing the SKMPP.

The research results showed that the Operating Standards that are often used in implementing the SKMPP in 
East Nusa Tenggara are socialization, fieldwork completion, data processing, and data entry. According to the explanation above, it can be concluded that the existing Operating Standards are very good in implementing the SKMPP in East Nusa Tenggara.

The distribution of responsibilities is an activity that significantly influences the implementation of the SKMPP. The distribution of responsibilities within East Nusa Tenggara Province's Office of National Land Agency is carried out structurally, meaning that the highest level of authority has the rule to directly regulate his subordinates. Policy executors in carrying out their duties help one another and work together and compete healthily. This can lead to a healthy work environment resulting in policy executors can continue to look for innovations to improve the implementation of the SKMPP in East Nusa Tenggara Province's Office of National Land Agency.

The dissemination of responsibility is an activity influencing the policy of SKMPP. That dissemination of responsibility in East Nusa Tenggara Province's Office of National Land Agency is already excellent, but there are some problems from the executors, such as often delaying the entry of data on the SKMPP. There have not been any significant changes today because there are still several executorss carrying out their activities in their fields without deliberately forgetting data entry in the SKMPP reporting application. Moreover, there is no firmness and suitable solution to the implementers, so that the same problem is still happening today.

Organizational structure is a framework of work patterns and task groups or functions of organizational parts that will be used to achieve organizational goals. The forms of organizational structure, among others; Organizational Structure based on function, Organizational Structure based on product/market, and organizational structure matrix.

With the organizational structure, organizational goals will be more easily achieved because there is a clear division of functions and authority. The organizational structure also illustrates whether there are concurrent positions in an operation that produces the same results. According to the provisions of the Internal Control System and Good Corporate Governance, a good organizational structure must have a separation of functions between operation and function, authorization and function, storage and function, and record and function. The organizational structure is a strategic tool for organizational management because it separates precise functions and powers, and concurrent positions regulated under statutory regulations for operations that produce the same results. After separating precise functions and authority, the company can determine the people who are following the place and expertise to make it easier to plan the position levels and requirements and the search for desired officials. The organizational structure is very influential in the success of an organization, especially in overcoming its human resource problems. Each organization will make a different organizational structure through organizational goals, company culture, work activities, and business patterns.

\section{CONCLUSION}

Based on the discussion above, the conclusions are as follows:

1. The communication that was built at East Nusa Tenggara Province's Office of National Land Agency related to the Land Programs' Quality Control System went well. However, the self-awareness to fill the results of completion at each stage of activities into the SKMPP reporting application should be strengthened to avoid the procrastination in data charging due to other works.

2. Resources in the form of apparatus and facilities to implement the SKMPP are adequate, but the problem is that the apparatus prioritizes completion and reporting of work/activities in their respective fields and forgetting to enter data on the SKMPP.

3. Dispositions made by officials in dealing with street vendors' arrangements are excellent, but incentives must be paid to the apparatus who carry out the policy.

4. Bureaucratic structure related to Operational Standards and the spread of responsibilities in implementing the SKMPP has been perfect, but the implementing agency has not seen any significant changes to date.

\section{SUGGESTION}

1. It is necessary to establish excellent communication between superiors and subordinates so that the information is not biased.

2. Conducting ongoing socialization and coaching to executors about the importance of SKMPP so their awareness will grow towards the importance of SKMPP.

\section{REFERENCES}

1. Winarno, Budi, 1998, Kebijakan Publik, Yogyakarta: Media Pressindo. Winarno, Budi, 2002, Kebijakan Publik teori dan proses, cetakan kedua,

2. Miles, Mattew B dan Amichael Huberman. 2007. Analisis Data Kualitatif Buku Sumber tentang Metode-Metode Baru. Terjemahan Tjetjep Rohendi Rohisi. Jakarta: Universitas Indonesia.

3. Islamy, M Irfal, 2001. Prinsip-prinsip Perumusan Kebijakan Pemerintah. Jakarta: Bumi Aksara 
4. Solichin, Abdul Wahab.2004, Analisis Kebijakan dari Formulasi ke Implementasi Kebijakan Negara, Edisi Kedua, Jakarta.Bumi Aksara.

5. Lester, James P, dan Joseph Stewart, JR. 2000. Public Plicy : An Evolution Approach. Wadsworth

6. Wibawa, Samudra, 1994. Evaluasi Kebijakan Publik. Jakarta : Raja Grafindo Persada

7. Edward,III.1980. Implementation Public Policy. Congresional Quarter Press. Washington DC.

8. Setiawan, Johny. 1988. Pemeriksaan Kinerja: Performance Auditing. Yogyakarta: BPFE.

9. Dwiyanto, Agus, 1995. Penilaian Kinerja Organisasi Pelayanan Publik. Yogyakarta: Fisipol UGM 